\title{
Combustion Property Improvement of Poorly Combustible Coal by Co-Firing of Agglomerates Consisting of Biomass-Calcium Carbonate and Coals (I): \\ Co-Firing Characteristics in Circulating Fluidized Bed Combustion of Poorly Combustible Coals
}

\author{
Toshihiko Maruyama ${ }^{* 1}$, Chuichi Mizoguchi ${ }^{* 2}$, Satoshi NAITo ${ }^{*}{ }^{\dagger}$, Nozomu Sonoyama $* 4$, \\ Yasuhiro SAKURAI ${ }^{*}$, Hiroyuki MATSUMOTO ${ }^{* 5}$, and Hideki HAYASAKA $* 6$
}

(Received November 10, 2017)

\section{難燃焼性石炭のバイオマスー炭酸カルシウム・石炭系燃焼助剂混焼による燃焼性等改善 ( I ) 一循環流動層燃焼における石炭・燃焼助剂の混焼特性一}

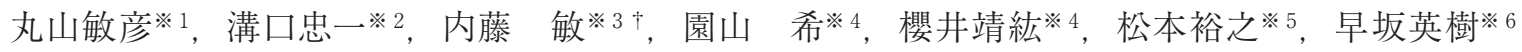

Binder less briquette of Coal Combustion Improver (CCI), which consists of pulverized coal and the same quantity of lime cake or paper sludge on dry basis, has been developed to improve combustibility of bituminous coal. Co-firing characteristics of the CCI was studied by bench-scale circulating fluidized bed combustion furnace at $850{ }^{\circ} \mathrm{C}$ under the blending ratio of $90 \%$ of bituminous coal with $10 \%$ of crushed CCI. The results showed that the CCI improved the combustibility of the coal and fly ash properties, and decreased emission of air pollutants. It was explained on the mechanism that fast pyrolysis of the CCI leads to decompose the CCI into the various size of particles, which is the compounds of coal and lime cake or paper sludge, and then the particles easily burn and interact each other in very short time in the combustion zone.

\section{Key Words}

Industrial waste utilization, Fluidized bed combustion, Biomass

難燃焼性石炭の燃焼性改善に向けて, 微粉炭および製糖排出ライムケーキ (LC)，または製紙排出ペーパースラッジ (PS) を乾燥重量基準で等量かつバインダー無しで加圧造粒した燃焼助剤 (CCI：Coal Combustion Improver) を開発した。本 CCIによる燃焼性改善効果を確認するため, ベンチスケールの循環流動層燃焼炉を用いて, 石炭に対してCCIを 10\%混焼 して検討した。 $850^{\circ} \mathrm{C} に$ に打試験の結果より, 石炭と CCI を混焼すると灰中未燃分が減少し, 排ガス中 $\mathrm{SO}_{2}$ 濃度が減少 し, フライアッシュの性状が改善された。これは, 火炉投入時にCCI が加圧造粒前の微粉炭および LC 粒子または PS 粒子, あるいはそれらの複合粒子へに直ちに解離し，燃焼場において相互的に作用したためと考えられた。

キーワード

産業廃棄物有効利用，流動層燃焼，バイオマス

※ 1 Technology Coordinate Institute, Maruyama

3-10, Higashi 3 Chome, Kita4ljyo, Higashi-ku,Sapporo-shi, Hokkaido 007-0841, Japan

※2 The Society of Chemical Engineers, Japan-SCE:Net 4-6-19, Kohinata, Bunkyo-ku,Tokyo 112-0006, Japan

※3 Kumagaigumi Co., LTD

2-1, Tukudo-Cho, Shinjuku-ku,Tokyol62-8557, Japan

※4 Idemitsu Kosan Co., Ltd

3-1, Nakasode, Sodegaura, Chiba 299-0267, Japan

$※ 5$ Kushiro Coal Mine Co., Ltd

5-2-23, Okotsu, Kushiro-shi, Hokkaido 085-0811, Japan

※6 Nippon Paper Industries Co., Ltd

Ochanomizu Sola City4-6, Kandasurugadai, Chiyoda-ku,

Tokyo 101-0061, Japan

$\uparrow$ Corresponding author: snaitou@ku.kumagaigumi.co.jp

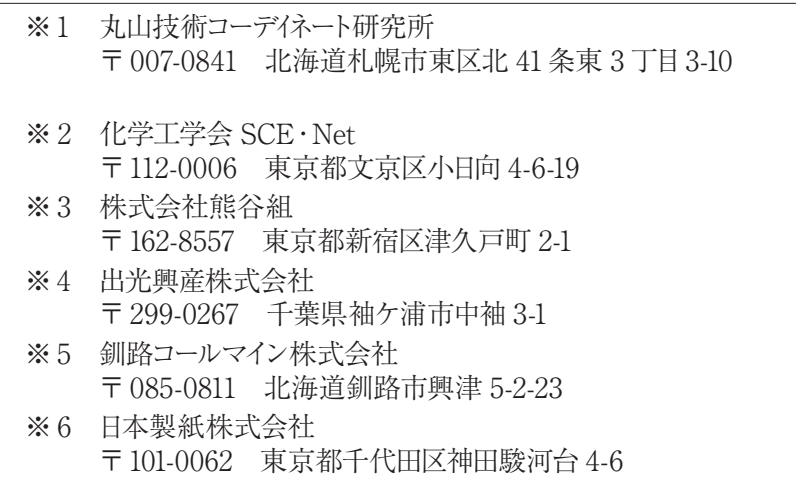




\section{1. はじめに}

わが国における一次エネルギーの $20 \%$ 以上を占める石炭 は, ベースロード電源の火力発電等に欠かせないエネルギー として, 今後も大量に輸入される海外炭を中心としてその重 要な位置付けは変わらない。現在, 様々な国・炭田からの炭 質・炭種別石炭を選定・確保しながら, 混炭利用技術と共に, 燃焼・発電技術の大きな進展によって, 高い水準でのボイラ 効率拈よび発電効率の向上が図られている。

一方, 石炭燃焼で発生する温室効果ガス対策上, 石炭使 用量節減によるさらなる省エネルギー，および今後の良質な 海外一般炭の選定・確保上の制約から, 多炭種の拡大を進 める上で, 難燃焼性石炭の燃焼, ガス化および発電効率向 上に関する技術開発が急務である。

温室効果ガス低減に向けたバイオマス利用の石炭混焼で は，微粉炭・木質バイオマス（約 $3 \mathrm{cal}$ \%) 混焼技術が実用 化されるとともに，木質バイオマス低温炭化物の最大混合率 $25 \mathrm{cal} \%$ とした微粉炭・トレファイドペレット混焼，および木 質ペレット $30 \mathrm{cal}$ \%のの循環流動層石炭混焼による小規模発 電所の事業化計画も進められている。

石炭・バイオマス利用に関しては, 第二次石油危機を契機 に，著者らは難燃焼性石炭の着火・燃焼性等を改善した石 炭・木質バイオマス複合固形燃料「バイオコール（別名：バ イオブリケット)」を開発した ${ }^{1)}$ ４)。バイオコールは，微粉 炭と木質等バイオマス粉を $80: 20$ で配合し, 脱硫剤（石灰 粉）を添加した混合物を，バインダレスで高圧ロールプレス により連続的に種々の形状・寸法に成形したブリケット燃料 である。煤煙, $\mathrm{SO}_{2}$ 排出量も削減し, 石油代替の民生・中 小型ボイラ用燃料として注目され, 開発後, 北海道内に年間 6,000 トンの生産工場も建設された。さらに，途上国を対象 とした技術移転活動 ${ }^{5)}$, NEDO 等事業による中国・インドネ シアにおける各々, 年間 5 万トン生産の実証プラント建設, および ODA (円借) の大型生産プロジェクト等の現地化活 動に係る中で, 省エネルギー・環境調和型石炭燃焼技術とし てその評価も得た。一方, 大規模生産計画において, 副原 料である分散型バイオマス資源の量的な確保・集荷，および 受給上のリスクに加えて, 乾燥・粉砕の特有な原料化による 処理コストが, 事業性評価に大きく影響した。

バイオマスを量的に価值化利用する観点から，小型燃焼 機による石炭 $(80 \%)$ ・バイオブリケット $(20 \%)$ 混焼におけ る石炭の燃焼性等改善効果, および石炭単味と同等の混合 微粉砕性も NEDO 委託事業・新エネルギーベンチャー技術 革新事業で基礎的に確認した。また，上記混合物の微粉砕 物（バイオマス含有量：4\%）の流通式熱天秤による流動混 焼試験の結果, 微粉炭の着火性改善, NOx 発生量の低減 効果等, 新たな燃焼特性を基礎的に確認した ${ }^{6)}$ 。バイオマス 一合成炭酸カルシウム（ライムケーキ： $4 \%$ 配合）と微粉炭混 焼の基礎的な検討を行い, バイオマス (蛋白質等) 含有率 が $0.4 \%$ において, 微粉炭の着火・燃焼（火炎伝播）性が大 幅に改善することを明らかにした7)。

著者らは，バイオマス配合による石炭燃焼性等改善に係
る知見に基づき, 製糖工場の産業排出物であるライムケー キ（LC）および製紙工場の産業排出物であるペーパースラッ ジ（PS）の有効利用のため, LC, または PS と粉状石炭によ る造粒化燃焼助剤 (以下, CCI : Coal Combustion Improver) の開発を進めた。CCI はバイオマス・炭酸カルシウム, 石炭 複合系の造粒物であり, バインダレス成形によって通常の貯 蔵・ハンドリング，輸送等に耐え得る強度を与える。CCI 製 造では, 乾燥重量基準で, LCまたはPS50：石炭50の混 合加圧成形物の量産化技術開発を進めた。成形法は, 原料 水分, LC, および PS 組成のバイオマス形状・量によって異 なるため, 経済性の観点から, 乾燥原料の高圧成形法 8) 9), または低圧原料成形 (押出し・圧搾脱水) 後の乾燥法 10) 検討して採用する。

LC，またはPSを原料とする CCIでは，いずれも独自の 混焼特性を有するが，PSを排出する製紙工場は全国に立地 しているため, 広域的に PS 原料の確保は可能である。一方, 地域的な製糖排出物の LC は, 量的確保上の制約を受ける。 そこで, 広域的に確保可能な古紙等, および石灰粉の湿式 混合・粉砕, 圧搾脱水による, バイオマス量の少ない LC 類 似組成物の CCI 原料化を基礎的に確認した ${ }^{9)}$ 。

本稿では, 高圧造粒 CCIの循環流動層混焼による難燃 焼性石炭の燃焼性改善, および炉内灰改質等に係る多面的 効果について, 燃焼助剤の原料組成, 難燃焼性石炭混焼特 性等から考察する。

\section{2. 実 験}

\section{1 燃焼助剤 $\mathrm{CCl}$}

\subsection{1 原 料}

CCI に使用した LC および PS の性状・原料組成を Table 1 に示す。その組成比については, 乾燥 $\left(105^{\circ} \mathrm{C}\right)$ 後, $500^{\circ} \mathrm{C}$ および $900^{\circ} \mathrm{C}$ の酸化加熱処理で, バイオマス燃焼および炭酸 カルシウム分解による重量減少から概算し, 鉱物組成はX 線回析分析法で同定した。

LC は甜菜糖液の精製時に圧搾脱水物(含水率 31 ～33\%) として排出されるが, その乾燥物は $90 \%$ 近くの微粒合成炭 酸カルシウム (一次粒子径: 約 $2 \mu \mathrm{m}$ ) と蛋白 (色素等) 質 のバイオマス約 $10 \%$ を有する特徵的な性状の組成物である。

PS は, クラフトパルプ, サーモメカニカルパルプ, および 脱墨古紙パルプ等プロセスによって得られる原料パルプの性 状・組成等がそれぞれ異なる。本実験では, PS は工場 A の新聞紙系古紙原料からのスラリー状 PS の圧搾脱水物であ る。

Table 1 Properties of lime cake (LC) and paper sludge(PS)

\begin{tabular}{c|c|c|c|c}
\hline Moisture & Waste (\%) & \multicolumn{3}{|c}{ Composition (\%,d.b.) } \\
\hline & Moisture & Biomass $^{* 1}$ & $\mathrm{CaCO}_{3}{ }^{* 2}$ & Others $^{* 3}$ \\
\hline LC & 31.0 & 9.8 & 87.5 & 2.7 \\
\hline PS & 46.9 & 29.0 & 44.3 & 26.7 \\
\hline
\end{tabular}

${ }^{* 1}$ biomass: LC (pigment), PS (wooden fiber)

${ }^{* 2}$ procipitated calcium carbonate

*3 others: PS (contains kaolinite) 
Table 2 Approxinate,sulfur analysis and calorific value of coals used

\begin{tabular}{c|c|c|c|c|c|c|c|c|c|c}
\hline Coal & $\begin{array}{c}\text { Moisture } \\
(\%)\end{array}$ & $\begin{array}{c}\text { Ash } \\
(\%)\end{array}$ & $\begin{array}{c}\text { VM } \\
(\%)\end{array}$ & $\begin{array}{c}\text { FC } \\
(\%)\end{array}$ & FR $^{*}$ & $\begin{array}{c}\text { TS* } \\
(\%)\end{array}$ & $\begin{array}{c}\text { S (combus.) } \\
(\%)\end{array}$ & $\begin{array}{c}\text { N } \\
(\%)\end{array}$ & $\begin{array}{c}\text { HHV } \\
(\mathrm{MJ} / \mathrm{kg})\end{array}$ & $\mathrm{HI}^{*}$ \\
\hline Aus.NL & 2.6 & 15.6 & 27.7 & 54.1 & 1.95 & 0.26 & 0.13 & 1.47 & 28.1 & 59 \\
\hline Aus.A & 2.6 & 14.4 & 30.3 & 52.7 & 1.74 & 0.55 & 0.48 & 2.03 & 28.4 & 50 \\
\hline KCM & 5.3 & 15.4 & 40.1 & 39.2 & 0.98 & 0.23 & 0.03 & 1.12 & 25.9 & 37 \\
\hline Aus.B & 5.3 & 12.8 & 41.5 & 40.4 & 0.97 & 0.60 & 0.58 & 1.42 & 27.6 & 38 \\
\hline
\end{tabular}

* FR: fuel ratio, TS: total sulfur, HI: Hardgrove Grandability Index

CCI に使用した石炭は Table 2 に示すAus. NL 炭 (豪州 NL 炭), Aus. A 炭 (豪州 A 炭), KCM 炭, およびAus. B 炭 (豪 州 B 炭) である。

\subsection{2 製造方法}

本実験に供したCCIは，LCまたはPS50 及び石炭 50 wt.\%（無水ベース）から成る加圧成形物で, 以下のよう な製法で試作した 8) 9)。なお，CCIの原料配合では複合燃焼 助剤として成形物強度・発熱量等からその基本配合とした。 LC, または PS は, 乾燥・破砕 (水分 $6 \sim 8 \%$, 粒径 $2 \mathrm{~mm}$ 以下) し, 石炭は, 風乾・粉砕 (2 $\mathrm{mm}$ 以下) した。各粉状 原料を無水基準で 50:50で混合し，ダブル・ロール式高圧 成形機 (バインダレス, 線圧力 : 5 トン $/ \mathrm{cm}$ ) を用いて成形 した。高圧成型したCCI を破砕, 篩分けし粒径 $1 \sim 5 \mathrm{~mm}$ に整粒した。

\section{1 .3 燃焼試験試料}

循環流動層燃焼試験において，専焼および燃焼用石炭と して選定した石炭は，Aus.NL炭およびAus.A 炭である。試 料は, 粒径 $1 \sim 5 \mathrm{~mm}$ に粉砕・整粒した。

CCI 混焼試料は，調製した石炭との配合比を $1: 9$ とした 混合物である。

\section{2 実験方法}

Fig. 1 は，上記試料を用いて燃焼試験を行ったベンチス ケールの循環流動層炉の概略である。燃焼試験では, 循環 流動層炉において定点温度 $850 \sim 860^{\circ} \mathrm{C}$, 排ガス中酸素濃 度 3 〜 \% を維持した条件下で供給した燃料を流動子(微粒 アルミナ）と共に, 一次 (ホット) サイクロンを通して循環さ せ，安定した燃焼の維持に要する給炭量/時間を測定した。 併せて, 燃焼系外に排出される灰は二次サイクロン，および バグフィルター集塵機で回収と共に, 排ガス組成等は $\mathrm{SO}_{2}$.

NOx を含めて測定した。

\section{3 各種分析, 測定}

回収したサイクロン灰およびバグ灰の灰中未燃分は, 試料 を塩酸処理により未反応の炭酸カルシウムを分解後, 元素 分析 (JIS M 8819, LECO 社) により炭素含有量を定量した。 粒度分布は, レーザー回折装置（HORIBA）を用い，粒子密 度は $\mathrm{N}_{2}$ 置換により測定した。

微量元素溶出成分 (六価クロム・ヒ素・セレン・ホウ素・フッ 素）はイオン交換水と試料を質量比 10:1 で混合後，24 時間 振とうし, ろ液中の微量元素含有量を ICP-MS（パーキンエ ルマー社，ELAN DRC II）にて測定した。

灰タブレットの圧壊強度は, 鋼球押し込み法により測定し

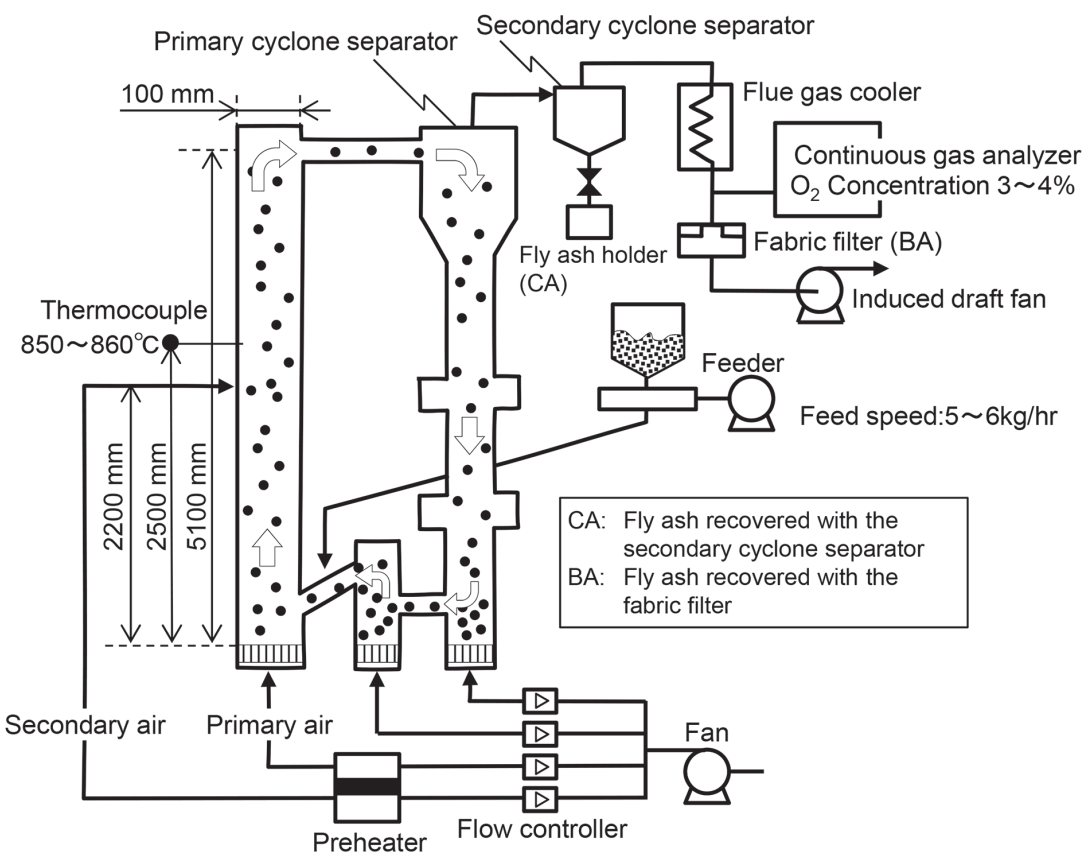

Fig. 1 Outline of circulating fluidized bed combustion furnace 
た。試料の外観は, 実体顕微鏡および電子顕微鏡 $(\mathrm{SEM})$ にて, 観察した。

\section{3. 結果と考察}

\section{$3.1 \mathrm{CCl}$ 混焼による着火性改善}

Fig. 2 は石炭専焼との比較で示した LC ・ C CI 混焼の炉内 温度分布である。それぞれの温度分布から，NL炭はバイ オマスを含む CCI 混焼によって, 石炭・バイオマスブリケッ 卜燃料 1) 3 と同様に燃焼性と係る着火性が改善されたと考 えられた。

CCI 混焼による燃焼性は，CCI 中バイオマスが少量であっ ても，その改善は期待でき， LC・CCIでは着火・燃焼性に 優れる非瀻維質バイオマス量は石炭・CCI 混合燃料の僅か, $0.3 \%$ 程度である。それに対して, PS・CCI では径約 $15 \mu \mathrm{m}$ の短繊維状で極めて着火・燃焼性に優れる木質バイオマス 量を，LC·CCI 混合燃料の 3 倍程度（Table 1) を含有する。

石炭・CCI 混焼試験における給炭量/時間, CCI 混焼灰 中未燃分，および死中未燃分より算出した燃焼効率を示した のが Table 3 である。

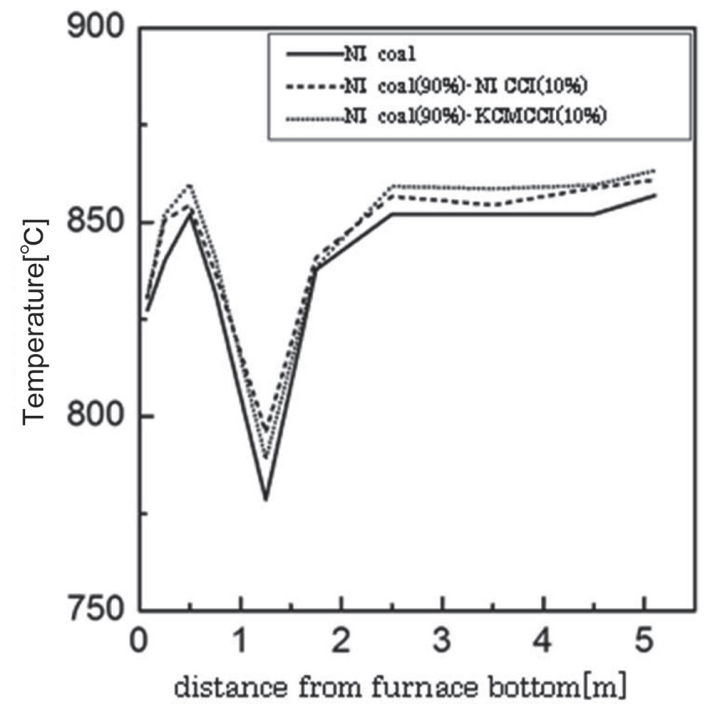

Fig. 2 Combustion temperature distribution of fuels in furnace
専焼時の NL 炭に比して, 給炭量の大きい豪州 A 炭では, PS C CCI 混焼によって, 所定燃焼条件の維持に要する給炭 量は大幅に減少した。これは, PS·CCIの混焼時に分裂した, 燃焼性に極めて優れる木質繊維質単粒子が石炭粒全体に分 散, 燃焼し, 専焼に比して給炭, 燃焼空気量とも, 少ない 量で所定燃焼条件を維持し得たと考えられた。

\section{$3.2 \mathrm{CCl}$ 混焼灰中未燃分と燃焼効率}

本試験では燃焼灰は約 $90 \%$ のイクロン $(\mathrm{C}) \cdot$ ・゙グ (B) 灰と $10 \%$ のボトム灰として分配, 回収されたが, Table 3 に 示すように, LC · CCI 混焼 $(\mathrm{C} \cdot \mathrm{B})$ 灰では専焼灰に比べて, 灰中未燃分が低減した。灰中未燃分より計算した燃焼効率か ら, 石炭への CCI 混焼による燃焼効率の向上が期待された。 一方, PS · CCI 混焼灰では, 燃料供給速度 (Table 3) か ら予想された灰中未燃分の低減効果は見られなかった。そ の理由として, CCI 混焼時にPS から単離した繊維状バイオ マス炭化物は一部, 循環燃焼されずに, 極軽量で, 微小な千ャ 一(炭素分) 粒子はサイクロン・バグ集塵機で回収された結 果と考えられた。

\section{$3.3 \mathrm{CCl}$ 混焼による大気污染源の発生性}

$\mathrm{SO}_{2}$ および $\mathrm{NOx}$ 発生性に関しては, LC, PS・CCI 混焼に よる脱硫率は， $\mathrm{Ca} / \mathrm{S}$ (モル比) との関連で，また， NOx 発 生量は酸素濃度 $6 \%$ 換算值と合せて, Table 4 に示した。な お，表中には LC 単味混焼による脱硫率，および NOx 濃度 も併記した。

脱硫率は, 明らかに LC ・ CCI 混焼による効果が大きく, 特に燃焼性硫黄分 $(0.13 \%)$ の低い $\mathrm{NL}$ 炭との混焼であっても, $\mathrm{KCM} \cdot \mathrm{CCI}$ 混焼による脱硫率が極めて高く，99\%に達した。 また, PS・CCI混焼でも，燃焼性硫黄分 $(0.48 \%)$ の高い 豪州 A 炭に対して, PS · CCI 中の Ca成分との効率的な反 応によって, その含有量に見合うだけの脱硫効果が示された。 脱硫効果の理由は，一義的には LC および PS 中に含有す る極微小で, かつ反応性に富む合成炭酸カルシウムに求め ることができる。それに加えて, 石炭混炭系, および石炭, バイオマス混焼系にはない, CCI 造粒物と石炭の混焼特有

Table 3 Results of co-firing poor combustible coal $\cdot \mathrm{CCl}(9: 1)$ mixtures

\begin{tabular}{c|c|c|c|c|c|c|c}
\hline & Mono fired & \multicolumn{2}{|c|}{ Co-fired LC·CCI } & Mono fired & \multicolumn{3}{c}{ Co-fired PS·CCI } \\
\cline { 2 - 8 } & Aus.NL & KCM & Aus.NL & Aus.A & KCM & Aus.B & Aus.A \\
\hline Supply (kg/h) & 3.41 & 4.2 & 3.52 & 4.8 & 2.55 & 2.56 & 2.78 \\
\hline Umburned (\%) & 14.3 & 4.9 & 8.7 & 10.8 & 9.4 & 11.2 & 9.5 \\
\hline combus.eff. (\%) & 96.7 & 98.9 & 97.8 & 98 & 97.8 & 97.5 & 97.9 \\
\hline
\end{tabular}

Table 4 Enviromental emission in co-firing $\mathrm{CCl}$ and mono firing coal

\begin{tabular}{c|c|c|c|c|c|c|c}
\hline & mono fired & \multicolumn{2}{|c|}{ co-fired LC·CCI } & mono fired & \multicolumn{3}{|c}{ co-fired PS·CCI } \\
\hline & Aus.NL & KCM & Aus.NL & Aus.A & KCM & Aus.B & Aus.A \\
\hline $\mathrm{SO}_{2}(\mathrm{ppm})$ & 140 & 1.4 & 4.2 & 376 & 116 & 164 & 124 \\
\hline desulfur. $(\%)$ & - & 99 & 97 & - & 69 & 55 & 67 \\
\hline $\mathrm{Ca} / \mathrm{S}$ & 1.5 & 5.6 & 6.0 & 0.2 & 2.2 & 2.1 & 1.6 \\
\hline $\mathrm{NO}_{\mathrm{x}}\left(\mathrm{ppm}, 6 \% \mathrm{O}_{2}\right)$ & 106 & 220 & 134 & 147 & 185 & 153 & 164 \\
\hline
\end{tabular}


の燃焼場形成に起因したと考えられた。なお，LC単味混焼 による脱硫率は高いが, その值は $91 \%(\mathrm{Ca} / \mathrm{S}: 6.0)$ であった。 NOx 発生性に関しては, NL炭, 豪州 A 炭専焼に比し て, LC および PS · CCI 混焼でその量が増大し, 特にLC · KCM 炭系の CCI 混焼でその増加量は顕著であった。それ は, 循環流動層による石炭の低温度 $\left(850^{\circ} \mathrm{C}\right)$ 燃焼では, 生 成 NOx は石炭質中 $\mathrm{N}$ 分由来のフューエル NOx が主体であ ることから, CCI 混焼による難燃焼性石炭質の燃え切り性の 向上（灰の未燃炭素の低下）でもたらされた。

\section{4 難燃焼性石炭・ CCI 混焼灰 (FA) の粉体特性}

\subsection{1 循環流動層混焼 FA の発生状況と改質・利用上の諸 特性}

循環流動層炉による CCI 混焼灰有効利用の可能性を検討 するため, PS ・ CCI 混焼灰について基礎的な評価を行った。 Table 5 にはCCI 混合燃料，および専焼用石炭ごとに，約 $0.5 \mathrm{~kg} / \mathrm{h}$ の発生速度で回収されたバグおよびサイクロン灰 への分配率を示した。サイクロン灰への移行が多く, 特に $\mathrm{KCM}$ 炭，および豪州 $\mathrm{A}$ 炭を原料とする CCI 混焼灰では, $80 \%$ 以上が粗粒灰のサイクロン灰として回収された。

上記分配率で回収されたFAについて，豪州 A 炭専焼灰 との比較で，CCI 混焼バグ，およびサイクロン灰の粒度分布 の一例を示したのが Fig. 3 (a) および (b)である。混焼灰か らの 2 次サイクロンで分級されたバグ灰（粒径 $10 \sim 20 \mu \mathrm{m}$ 以下）と粗粒サイクロン灰粒度分布は大きく異なり，他の混 焼バグおよびサイクロン灰それぞれで，同様なパターンの粒 度分布を示した。

上記の特徵的な粒径分布から, CCI 混焼の炉内処理によ る難燃性石炭混焼灰の性状・改質等に関して, 次の事項に 係る知見が得られた。

\subsubsection{CCI 混焼バグ灰の粒度構成改善}

混焼バグ灰は，CCIに使用する炭種，炭質とは関係なく， 易燃焼性の $\mathrm{KCM}$ 炭，および豪州 B 炭と同様に，難燃焼性 の豪州 A 炭であっても，専焼灰に比して，モード径（最高 頻度％）はその值を増しながら，メジアン径と共に同じよう な值となり，そのモード径も微粒側に移行しながら，粒度分 布幅も狭く，性状的に安定した粒度構成を呈した。

その裏付けとして，混焼バグ灰の粒子密度 $\left(\mathrm{g} / \mathrm{cm}^{3}\right)$ の測 定結果を Table 6 に, また, 電顕観察結果はFig. 4 に示した。 粒子密度は, いずれも専焼灰に比して僅かに増大した。また, 写真からは，専焼灰には粗灰粒子が多く見られるのに対し て, 混焼灰では粗粒灰の焼結・収縮による形状変化に伴う

Table 5 Ratio of bag and cyclone ashes from mono firing and co-firing PS. $\mathrm{CCl}$ of Australian coal A

\begin{tabular}{c|c|c|c|c}
\hline & Aus.A $^{* 1}$ & KCM $^{* 2}$ & Aus.B*2 & Aus.A $^{* 2}$ \\
\hline BA & 34.8 & 15.5 & 32.7 & 14.0 \\
\hline CA & 65.2 & 84.4 & 67.3 & 86.0 \\
\hline
\end{tabular}

(BA: bag ash, CA: cyclone ash )

${ }^{* 1}$ mono fired, ${ }^{* 2}$ co-fired
粒径の縮小等が観察された。

\subsubsection{CCl 混焼サイクロン灰の粗粒化と粒度構成}

一方, 専焼灰と比較した混焼サイクロン灰の粒度構成では, メジアン径，モード径とも大きくなり，モード径はその頻度％ を低めながら，粗粒側粒子径を高める粒径分布を呈した。 また専焼および混焼灰とも，粒子径 60 ～ $80 \mu \mathrm{m}$ あたりに肩 をもった分布曲線を示したが，それは燃焼流動子の一部が サイクロン灰として回収されたことによると考えられた。その ことを含めて, 燃焼灰の粒子・形状, 溶融・凝集状況等を 検討するために示したのが Fig. 5 である。

それら写真中には球状微粒の燃流動子, および CCI 混焼 灰の未燃分増大の原因の一つである短繊維木質からの微粒

(a)

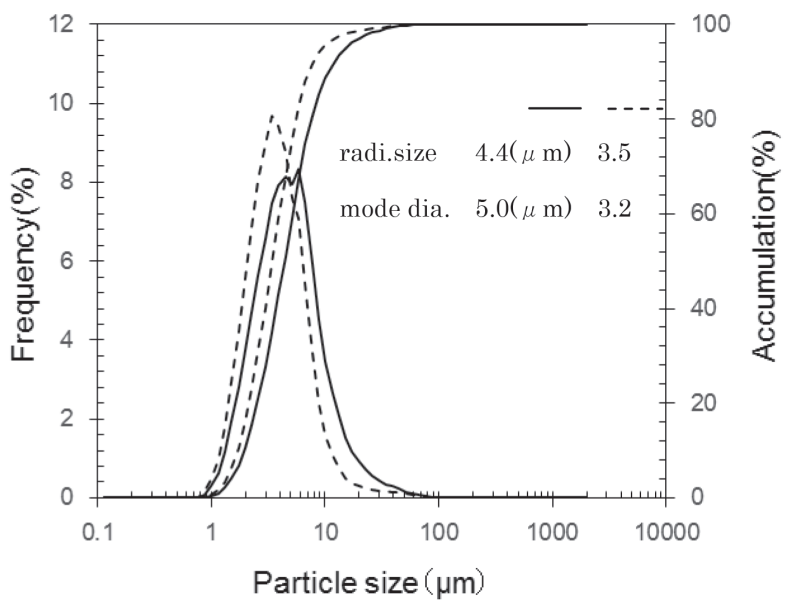

(b)

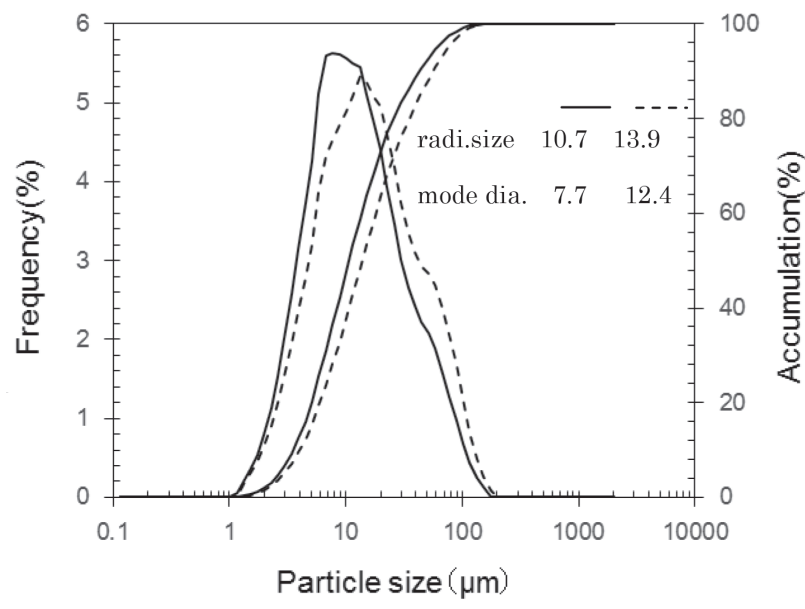

Fig. 3 (a) Particle size distribution of ashes from bag filter (Australian coal A - coal A $90+$ coal A $P S / C C l$ $10 \%$--- ), (b) Particle size distribution of ashes from cyclone (Australian coal A - coal A90 + coal A. PS/CCl10\% --- )

Table 6 Particle density $\left(\mathrm{g} / \mathrm{cm}^{3}\right)$ of bag ashes from mono firing and co-firing $\mathrm{CCl}$ of Australian coal A

\begin{tabular}{c|c|c|c}
\hline Aus.A (mono) & KCM·CCI & Aus.B·CCI & Aus.A.CCI \\
\hline 2.38 & 2.40 & 2.43 & 2.42 \\
\hline
\end{tabular}



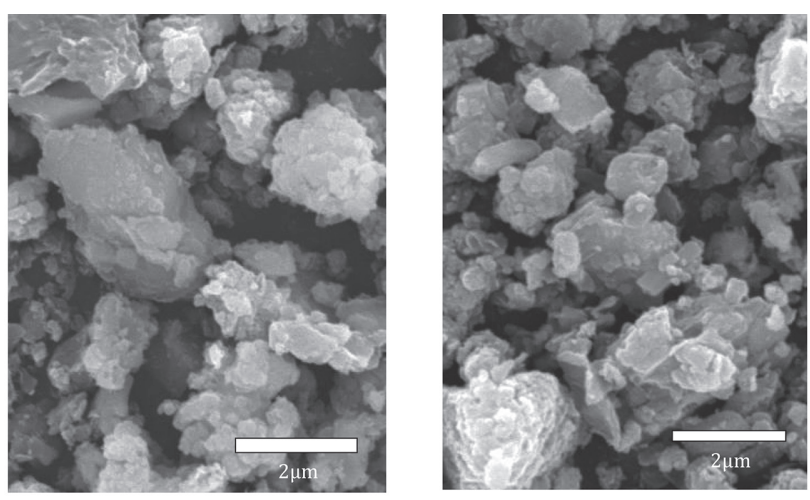

Fig. 4 SEM of ashes from mono fired and co-fired PS/CCI $10 \%$ of Australian coal A (left: mono fired bag ash, right: co-fired bag ash)
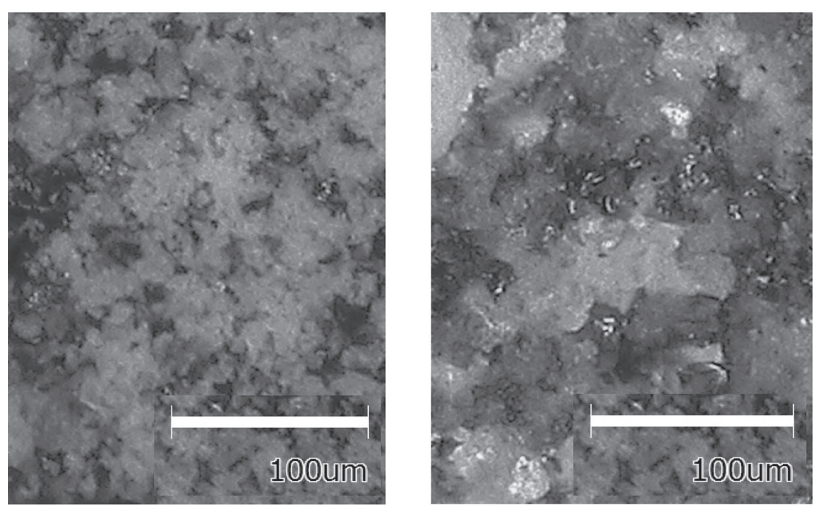

Fig. 5 Micrograph of ashes from mono fired and co-fired PS/ $\mathrm{CCl} 10 \%$ of Australian coal A (left: mono fired cyclone ash, right: co-fired cyclone ash)

な炭化物が僅かに識別される。そして専焼灰に比べ，粗粒 化した混焼サイクロン灰では，全体的に粒子の境界がより明 瞭化した集合体として観察される。それは，通常の循環流 動層（低温度： $850^{\circ} \mathrm{C}$ ）燃焼では起こり難い，灰粒子粒界の 溶融, 凝集による粗粒化であり, サイクロンの集塵効率化と 共に，混焼灰利用上の性状等改善の一つと考えられた。

CCI 混焼温度 $\left(850 \sim 860^{\circ} \mathrm{C}\right)$ での灰粒子粒界の焼結・溶
融について神谷等 ${ }^{12)}$ による $\mathrm{PFBC}$ 飛灰で, $870^{\circ} \mathrm{C}$ の熱履歴 を与え，灰粒子の局所的液相の生成に関する確認は，重要 な知見として，その考察の上での示唆を与えた。

上記，液相生成する温度付近までには，LCおよび PS · CCI 混焼でも達したものの, その現象は前者の混焼では起 きず，後者の PS · CCI 混焼で見られた。その理由としては, PSの木質繊維が多いことによる, 循環流動層炉での所定燃 燒条件を少ない給炭量（Table 3）で維持できる混燒特性と 関連していると考えられた。なお, 本 CCI 混焼灰では, $1,450^{\circ} \mathrm{C}$ の高温に曝される微粉炭燃焼 FAのように, 石炭含有鉱物 (カ オリナイト・イライト等の粘土鉱物）のムライト, アルミノケ イ酸塩等への形態変化によるものではなく，その灰生成温 度はカオリナイトからハロイサイトに変わる $1000^{\circ} \mathrm{C}$ 以下である ことは X 線回折で確認した。

\subsubsection{CCl 混焼灰の微量溶出金属成分}

循環流動層燃焼炬による低温度混焼で回収されたフライ アッシュ（FA）のサイクロン，およびバグ灰から溶出した 5 元素 (六価クロム・ヒ素・セレン・ホウ素・フッ素) の測定 結果を Table 7 に示した。

溶出 5 元素は石炭燃焼過程での挙動から, $\mathrm{Cr}(\mathrm{VI})$ はグルー プ1 (非揮発性), As, Se, B はグループ 2 (揮発一凝縮性), および F はグループ 3 (揮発一非凝集性) に分類されてい る ${ }^{11)}$ 。そのような溶出性元素の揮発・凝集性によって，専焼 および CCI 混焼のバグ, サイクロン灰への分配, 濃縮度に影 響を与える。

専焼灰ではいずれも, 非凝集性元素のフッ素はサイクロン 灰にはあまり濃縮せずに, 大部分はバグ扊への濃縮・付着, および系外に放出される。一方, CCI 混焼灰ではフッ素はサ イクロン灰と共に，その多くはバグ灰に濃縮・付着および灰 中 Ca 成分との反応・固定化したと考えられた。

揮発・凝集性のホウ素は, LC 混焼系ではフッ素と同様な 挙動をとるが, PS 混焼系とはサイクロン灰への分配度合い が大きくなる点で異にする。混焼時に生成するホウ素酸化 物とカルシウム成分の反応性が低いことに加えて, サイクロ ンで回収される粗粒灰の生成機構に関連すると考えられた。 また，非揮発性の元素 Cr（VI）は，本表中にあるように，

Table 7 Elution of heavy metal from mono fired ashes, and co-fired ashes with $\mathrm{CCl}$ *

\begin{tabular}{c|c|c|c|c|c|c|c|c}
\hline Eluted & Ash & $\mathrm{NL}^{* 1}$ & $\mathrm{KCM}^{* 2}$ & $\mathrm{NL}^{* 2}$ & Ash.A $^{* 1}$ & $\mathrm{KCM}^{* 2}$ & Ash.B $^{* 2}$ & Ash. $^{* 2}$ \\
\hline $\mathrm{Cr}(\mathrm{VI})$ & $\mathrm{BA}$ & $(-)$ & $(-)$ & $(-)$ & $(-)$ & $(-)$ & $(-)$ & $(-)$ \\
\hline & $\mathrm{CA}$ & $(-)$ & 0.32 & 0.18 & $(-)$ & $(-)$ & $(-)$ & $(-)$ \\
\hline As & BA & $(-)$ & $(-)$ & $(-)$ & $(-)$ & $(-)$ & $(-)$ & $(-)$ \\
\hline & CA & $(-)$ & $(-)$ & $(-)$ & $(-)$ & $(-)$ & $(-)$ & $(-)$ \\
\hline Se & BA & $(-)$ & $(-)$ & $(-)$ & $(-)$ & $(-)$ & $(-)$ & $(-)$ \\
\hline & CA & $(-)$ & $(-)$ & $(-)$ & $(-)$ & $(-)$ & $(-)$ & $(-)$ \\
\hline B & BA & 0.6 & 0.2 & 0.6 & 1.0 & 1.3 & 1.1 & 1.1 \\
\hline & CA & 0.2 & 0.1 & 0.1 & 1.0 & 1.0 & 1.2 & 1.1 \\
\hline F & BA & 23.5 & 2.5 & 4.2 & 35.0 & 1.7 & 7.2 & 5.6 \\
\hline & CA & 2.5 & 1.0 & 0.9 & 0.1 & 1.8 & 2.4 & 2.5 \\
\hline
\end{tabular}

${ }^{* 1}$ mono fired ash, ${ }^{* 2}$ co-fired ash, * soil environmental standards (mg/l); $\mathrm{Cr}(\mathrm{VI}): 0.05$, As: 0.01, Se: 0.01, B: 0.8, F: 1.0 (BA: Bag Ash, CA: Cyclon ash), (-): ND 
比較専焼灰では基準值以下であるのに対して, LC・CCI 混 焼灰では，KCM，NL炭系 CCI 混焼灰において新たに基準 值以上の溶出が見られた。これは CCI 由来 Ca分が石炭灰 中の不溶性 $\mathrm{Cr}$ （III）の酸化を促進させたと推測された。

以上のように，混焼炉内処理では CCI 中 Ca 成分と FA 中 溶出元素の反応性等による重金属溶出抑制, 低減に対して 一様な効果は期待できないため, 最終的な FA 原料化処理 が必要である。その対応として, これまでに開発を進めてい るのが, FA 原粉の旋回噴流擋拌処理・湿式選択微砕化に よる粒度構成改善・溶出元素洗浄技術 13 ) 14), および FA 自 体のポゾラン性を利用したセメント配合等による硬化体化技 術である。

\subsection{5 石炭・CCI 混焼灰のセメント配合硬化特性}

セメント配合による燃焼灰の硬化性は, NL 炭, LC·CCI 系燃焼灰では $\mathrm{KCM}$ 炭・CCI 混焼のサイクロン灰のみに見ら れたのに対し, 豪州 A 炭, PS・CCI 系燃焼灰では, 専焼灰 及びサイクロン・バグ混焼灰のいずれにも確認された。Fig. 6 には, PS・CCI 混焼灰のタブレット硬化体におけるセメント 配合量と圧壊強度 (平均值：試料数 5) の関係を専焼灰との 比較で示した。

試料は各セメント量を配合した燃焼灰混合物（w/c：0.25） を加圧下でタブレット $\left(\mathrm{d}: 2.5 \mathrm{~cm}\right.$, 質量 $\left.3 \mathrm{~g}, 100 \mathrm{kgf} / \mathrm{cm}^{2}\right)$ 状に成形した硬化体（養生：1週）を使用した。タブレット 硬化体に対する圧壊強度は，これまでに粉状バイオマス・石 炭等混合物のバインダレス・高圧成形特性の指標 1) 8) とし ている, 圧子 (鋼球： $\phi 8 \mathrm{~mm}$ ) 押し込み法 (下降速度 : 10 $\mathrm{mm} / \mathrm{min}$.) により測定した。なお，本測定法は, タブレット 硬化体の破壊パターン等は微粉硬化体の圧縮強度, および その構成する粒子間結合力等の材料物性を反映する指標の 一つと考えている。

混焼サイクロン灰では，セメント配合混焼灰硬化体の圧壊
強度は専焼灰硬化体に比して, 明らかに増大した。その理 由として, 混焼灰では粒界焼結によるポゾラン反応性が付与 され, CCI 由来の反応性の高い生石灰を多く含有すると共に, 混焼灰の粒度構成改善等によると考えられた。

混焼バグ灰ではサイクロン灰硬化体と同様に, 専焼灰硬 化体に比して強度が増大し, 圧壊時の破壊(応力ー歪) パター ンは座屈から脆性破壊パターンへと移行する。それは, 前 述のサイクロン灰硬化体と同様に, 灰粒界の溶融焼結, 粒 度構成改善によると考えられた。

以上のように, 循環流動層混焼灰 $\left(850^{\circ} \mathrm{C}\right)$ であっても, $\mathrm{PC}$ 特有の原料組成 (Table 1) と関連してもたらされる硬化 特性によって, 高温微粉炭燃焼 $\left(1,450^{\circ} \mathrm{C}\right) \mathrm{FA}$ と同様なりサ イクルの可能性を得た。

\section{4. 最後に}

循環流動層燃焼において, 難燃焼性石炭はバイオマスー 炭酸カルシウム・石炭系 CCI 混焼によって, 燃焼性および灰 性状・粒度構成等改善に関わる知見が得られたが, その混 焼機構に関しては, 新たな燃焼場形成の観点から, 各 CCI の原料組成等との関連で以下に考察した。

1) 循環流動層炉における難燃焼性石炭・CCI 混焼による燃 焼場形成

所定粒度の一般炭の循環流動層燃焼では，火炉における 石炭粒は乱流下で良好な混合気を得ながら, 揮発分燃焼後 のチャーは効率的に循環燃焼される。その燃焼機構では, 難燃焼性石炭・CCI 10\%混合物が火炉投入時に CCI 中バイ オマスの着火に始まり, CCI は分裂しながら, 難燃焼性石炭 粒間により均一に分散し, 各粒子物質・生成物の混合燃焼 による燃焼場を形成した。

CCI 混焼による燃焼場は, 従来からの多炭種混炭燃焼, 石炭・バイオマス混焼等とは，燃焼効果の多面性で異にする

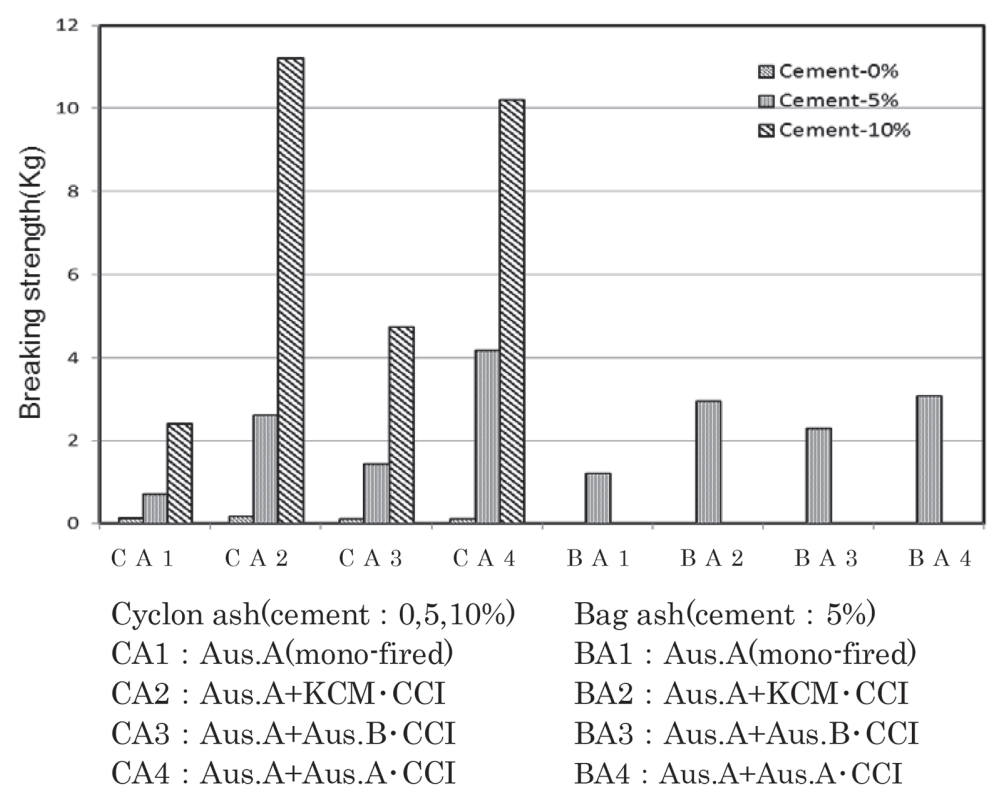

Fig. 6 Breaking strength of tablets added poor cement to bag/cyclone ashes mono-fired and co-fired with PS $\cdot \mathrm{CCI}$ 
新たな燃焼場形成として， LC ・ CCI 混焼および PS ・ CCI 混 焼ごとに以下に整理した。

2) 難燃焼性石炭・ LC 系 CCI 混焼場

ライムケーキと粉炭混合物の高圧成形・破砕物である LC·CCI は，火炉では原料組成ごとに LC，石炭粒子，お よびその複合粒子に分裂しながら，石炭粒子間に分散，全 体的に石炭粒全体の揮発分. チャ一燃焼を助長し, 石炭・ CCI 混焼による燃焼場を形成した。

CCI 混焼場では，僅かなバイオマス含有量であっても石炭 の着火性改善と共に, 安定燃焼へ関与し, 結果として燃え切 り性向上による灰中未燃分低減効果をもたらした。それに 加えて, CCI 中 Ca 成分との反応 - 固定化によって高い脱硫, および灰中溶出微量金属元素の低減，特に揮発・非凝集性 フッ素は, $\mathrm{SO}_{2}$ と同様に大きく低減した。

一方, CCI 混焼による石炭質の燃え切り性改善によって NOx 発生量の増大, また溶出微量金属元素の六価クロムは, Ca 成分の酸化作用で増大した。前者の NOx 低減には CCI 混合率，二段燃焼等による低 NOx 燃焼法，および後者の 重金属除去には，先述の湿式洗浄による燃焼灰の原料化前 処理法で対応する事項とした。

3）難燃焼性石炭・PS 系 CCI 混焼場

PS · CCI 造粒，破砕物は，火炉内で PS，石炭粒子，およ びその複合粒子への分裂に加えて PS 中の木質緎維粒子も 単離した状態で, 石炭粉中に均一分散・燃焼し， LC・CCI と同様な混焼機構を基本として, PS 原料組成に深く係る混 焼場を形成した。その特徵的な燃焼場形成に欠かせないの が，CCI 中バイオマスもその一つである。特に PSでは LC に比してその含有量は 4 倍程度と多く，しかも長炎燃焼性に 極めて優れた木質繊維（乾燥）を多く含有する。因みに，そ の量は石炭·CCI (10\%) 混炭の燃料全体の 1.5 質量\% (d.b.) に相当する。

その量は着火・燃焼性等改善に要する量よりも遥かに多く, 上述の単離木質繊維を含め, PS と一体化した木質繊維は, 燃焼助剤の原料のみならず，長炎燃焼の粉体燃料として燃 焼場形成に関与した。その結果，燃焼サイクロン・バグ灰粒 界部の溶融・焼結等をもたらした。

\section{謝 辞}

本報告は, (株) 熊谷組が主体となって, 釧路コールマイン (株)，日本製紙（株）と共同で実施した，北海道循環資源 利用促進税研究開発補助事業等で得られた成果をまとめた ものである。

本研究の実施に当たって,（株）ホソカワミクロンには CCI 試作, 実験試料調整, 及び (株) 北陽には関連各種試験, 及び日本甜菜糖（株）にはライムケーキ試料の提供にご協力 を頂いた。

CCI 混焼灰の評価等試験では，北海道総研機構・工業試
験場 高橋徹, 上出光志, 稲野浩行, 長野伸泰各氏, ノー スマテリアル(株) 古賀卓哉氏, 及び (株) 北陽谷口克典, 宮森護両氏にご協力を頂いた。

以上, 記して厚く感謝を申し上げます。

\section{文 献: References}

1) Maruyama, T.; Mizoguchi, C., Briquetting and Combustion of Coal-Wood Composite Fuel (Biocoal), 4th Inter. Sympo. on Agglomeration ED. C..E. Capes. AIME, (1985)

2) Maruyama, T.; Takemichi, S., Combustion Characteristics of Biocoal, Inter. Sympo. On Coal Combustion, Beijing in China, (1987)

3) Maruyama, T.; Mizoguchi, C., COAL-IN ASIAPACIFIC, NEDO, 4(3), 32 (1992)

4) Mizoguchi, C.; Koizumi, S.; Yamamoto, Y., J. Soc. Powder Tech. Jpn, 28(3), 149 (1991) : 溝口忠一, 小泉茂, 山本裕, 粉体工学会誌, 28(3), 149 (1991)

5) Maruyama, T., J. Jpn. Inst. Energy, 74(2), 70-77 (1991) : 丸 山敏彦, 日エネ誌, 74(2), 70-77 (1991)

6) Kamide, M.; Maruyama, T. et al., Meeting for Research Presentation, Hokkaido Branch, Japan Institute of Energy, Jan. 2010 : 上出光志, 丸山敏彦ほか, 微粉炭混 焼用石炭複合バイオマス燃料開発，第 10 回北海度エネル ギー資源環境研究発表会, 日本エネルギー学会, (2010.1)

7) Kamide, M.; Naito, S.; Maruyama, T. et al., Meeting for Research Presentation, Hokkaido Branch, Japan Institute of Energy, Feb. 2011 : 上出光志, 内藤敏, 丸山 敏彦ほか, 石炭・炭化物燃焼におけるライムケーキの燃焼 助剤特性, 第 11 回北海道エネルギー資源環境研究発表会, 日本エネルギー学会, (2011.2)

8) Patent 5394837 : 特許, ライムケーキのリサイクルのための 処理法

9) Patent 6118598 : 特許, 石炭燃焼助剂組成物及びその組 成物を用いた石炭の燃焼方法

10） Patent 5941183 : 特許, 混焼用燃焼助剤の製造方法及び この燃焼助剂を用いた燃焼用石炭の燃燒方法

11) Ninomiya, Y., J. Jpn. Inst. Energy, 92, 274-282 (2013) : 二 宮善彦, 日エネ誌, 92, 274-282 (2013)

12) Kamiya, H.; Tsukada, M., J. Aerozol Res., 20(1), 19-25 (2005): 神谷英博, 塚田まゆみ, エアロゾル研究, 20(1), 19-25 (2005)

13）Patent 2015-46940：特願，石炭燃焼灰の処理装置および 当該装置を利用した石炭燃焼灰の処理方法

14) Sakai, Y.; Iguchi, M.; Naito, S.; Maruyama, T. et al., Tetuto-Hagane, 103(3), 166-173 (2017) : 酒井祐介, 井口學, 内 藤敏，丸山敏彦ほか，鐵と鋼, 103(3), 166-173 (2017) 